\title{
AUTISM AND MMR VACCINE
}

\section{AUTIZAM I MMR VAKCINA}

\author{
Nataša Maksimović, Darija Kisić Tepavčević
}

\section{Summary}

Autism is a complex neurological developmental disorder with wide range of symptoms. Among them, poor social interaction, limited and repeated behavioral patterns are the most important for diagnosing the disorder. The prevalence of autism is rising constantly. One of the theories drawing the greatest public attention for a long time is a possible association between MMR vaccine and risk of autism. The first study aimed to investigate this association is the one conducted in 1998. As the results supported the theory that MMR vaccine increased the risk of autism, MMR immunization coverage decreased dramatically which further led to measles outbreaks, even in those countries where the disease was almost eradicated. Soon after that publication, new studies denying any association between MMR vaccine and risk of autism were published. Among them, systematic review published in 2012, including 57 epidemiological studies with 14.700 .000 children is particularly important. Although the etiology of autism is not completely clarified, there are strong evidence on the presence of neurobiological changes with significant genetic component underlying the etiology. According to recent literature data, morphological changes in brain of children age 6 to 12 months, that is, before the administration of MMR vaccine, precede clinical symptoms of autism.

Key words: MMR, autism, prevalence, etiology, epidemiological studies

\section{Sažetak}

Autizam je kompleksan neurološki razvojni poremećaj sa širokim spektrom simptoma, među kojima se izdvajaju slaba ili nikakva socijalna interakcija i komunikacija i ograničeni i ponavljajući obrasci ponašanja, kao najznačajniji simptomi za postavljanje dijagnoze. Prevalencija autizma je u stalnom porastu. Jedna od teorija koja već dugi niz godina budi pažnju javnosti je i teorija o mogućoj vezi između MMR vakcine i rizika za nastanak autizma. Prva studija koja je imala za cilj da ispita ovu povezanost, izvedena je još davne 1998. godine. Kako su rezultati ove studije govorili u prilog teorije da MMR vakcina povećava rizik za nastanak autizma, došlo je do pada obuhvata vakcinacije MMR vakcinom i do masovne pojave malih boginja i u onim zemljama gde su bile gotovo eliminisane. Ubrzo su usledile brojne studije koje su opovrgle svaku povezanost između MMR vakcine i rizika za nastanak autizma, među kojima je i sistematski pregled literature iz 2012. godine, koji je uključio 57 epidemioloških studija, sa 14.700 .000 dece. I ako etiologija autizma nije sasvim razjašnjena, postoje snažni dokazi o prisustvu neurobiološke osnove sa značajnom genetskom komponentom kod obolelih. Prema najnovijim leteraturnim podacima, morfološke promene mozga u uzrastu 6-12 meseci, dakle, pre dobijanja MMR vakcine, prethode kliničkom ispoljavanju autizma.

Ključne reči: MMR, autizam, prevalencija, etiologija, epidemiološke studije

\section{AUtizam - DefiniCIJA I DIJAgnozA}

Autizam je kompleksan neurološki razvojni poremećaj sa širokim spektrom simptoma, među kojima se izdvajaju slaba ili nikakva socijalna interakcija i komunikacija i ograničeni i ponavljajući obrasci ponašanja, kao najznačajniji simptomi za postavljanje dijagnoze (1). Autizam, zajedno sa pervazivni razvojnim poremećajem (PRP), nespecifičnim PRP i Aspergerovim sindromom (AS) čini spektar autističnih poremećaja (SAP) (2). Rana dijagnoza autizma je izuzetno važna jer omogućava pravovremeno uključivanje u posebne i specijalizovane programe, za koje je pokazano da značajno poboljšavaju komunikaciju i socijalnu interakciju (3). Kriterijumi za uključivanje $\mathrm{u}$ navedene programe često su ograničeni samo na onu decu koja imaju postavljenu dijagnozu SAP, što ukazuje na značaj ranog otkrivanja. S druge strane, teškoće koje mogu da se jave pri postavljanju dijagnoze autizma, kao i diferencijalno dijagnostički problemi kod najmlađih, često otežavaju rano otkrivaje autizma (4).

Dijagnoza SAP u najranijem uzrastu je moguća, ali je klinički teško izvodljiva zbog preklapanja sa značajnim i ozbiljnim govornim i opštim razvojnim poremećajima koji nastaju zbog mentalne retardacije $(3,5)$. Van Daalen i saradnici su 2009. godine objavili da čak i iskusni kliničari imaju nesuglasice kada je u pitanju diferencijalna dijagnoza SAP i mentalna nesposobnost bez poremećaja iz SAP kod dece uzrasta 2 godine (6), dok je Lord pokazao da su dijagnostičke razlike izraženije već u uzrastu od 3 godine $(3,5)$.

\section{PrevalenciJa AUtizima}

Leo Kanner je 1943. godine započeo seriju slučajeva dece sa autizmom, tvrdnjom da mu je ovo stanje prvi put privuklo pažnju 1938. godine (7).

Prve studije o prevalenciji autizma sprovedene su tokom 60-ih i 70-ih godina prošlog veka u SAD-u i u Velikoj Britaniji. Procenjena prevalencija autizma iznosila je 2 do 4 na 10.000 dece $(8,9,10)$. Ovakvi rezultati odavali su utisak da je autizam redak poremećaj. Takođe, prve studije prevalencije autizma ukazale su i na jasnu razliku između polova, pri čemu su dečaci čak 4 puta češće 
obolevali u odnosu na devojčice. Kada su ustanovljeni dijagnosički kriterijumi autizma krajem 80 -ih i početkom 90-ih godina XX veka, prevalencija autizma u svetu pokazala je dramatičan porast $(11,12,13)$.

Rezultati prospektivne kohortne studije koja je za cilj imala procenu prevalencije SAP u populaciji dece iz Velike Britanije, pokazala je da u njihovom reprezentativnom uzorku prevalencija iznosi 30,8 na 10.000 dece (14). Navedena prevalencija bila je slična prevalenciji koju su u svojoj studiji prijavili Bertrand i saradnici 2001. godine, a koja je iznosila 40,5 na 10.000 dece (15). U studiji koju su u Velikoj Britaniji 2009. godine sproveli Baron-Cohen i saradnici, pokazano je da je prevalencija autizma 94 na 10.000 dece, ukoliko se podaci o deci preuzimaju iz $\mathrm{Na}$ cionalnog registra, dok je prevalencija dobijena na osnovu skrininga i kliničke dijagnoze među decom uzrasta 5-9 godina nešto viša i iznosi 99 na 10.000 dece (16).

Počev od 2000. godine, CDC sprovodi aktivni nadzor nad SAP među osmogodišnjom decom u određenim centrima u SAD, na svake 2 godine (17). Prema procenama CDC-ja, prevalencija u SAD-u je 2000. godine iznosila 6,7 na 1000 dece, a njena vrednost je do 2010. godine porasla dvostruko više, na 14,7 na 1000 dece $(1,5 \%)(18-20)$. Iako autizam može biti dijagnostikovan već u usrastu od 2 godine, u SAD-u je medijana uzrasta $5,2-5,7$ godina $(21,22)$. Prema podacima CDC-ja, kod većine dece u SAD-u procena psihomotornog razvoja se obavlja do uzrasta od 8 godina. Iz ovog razloga, CDC analizira prevalenciju autizma u uzrastu od 8 godina, a potom na svake dve godine, jer je to najefikasniji način da se sagleda da li postoje promene u vremenskom trendu prevalencije (23).

Jedna od prvih epidemioloških studija koja je sprovedena na teritoriji Meksika pokazala je da je prevalencija dece sa SAP $0,87 \%$, što je u saglasnosti sa prethodno objavljenim pregledima literature iz 2009. godine, prema kojima se prevalencija kretala $0,6-1 \%(11,24-26)$. Prevalencija u Latinskoj Americi je nešto niža. U Venecueli je 2008. godine iznosla $0,17 \%$ za sve poremećaje iz SAP, i to $0,11 \%$ za autistični poremećaj, i $0,06 \%$ za Aspergerov sindrom, u populaciji dece uzrasta 3 - 9 godina (27).

Prema rezultatima studije sprovedene u Južnoj Koreji 2015. godine, prevalencija autizma je nešto viša i iznosi $2,64 \%$ kod dece uzrasta $7-12$ godina. Ovi rezultati su upadljivi ne samo zbog činjenice da je procenjena prevalencija viša u odnosu na onu koju su 2012. godine dobili Elsabaggh i sar (19-25), već i zbog toga što je 90\% dece sa autizmom išlo u redovnu školu, dok $72 \%$ njih nije imalo nikakav psihijatrijski poremećaj u ličnoj anamnezi (28).

Statistički podaci koji se odnose na prevalenciju autizma u odabranim zemljama sveta za 2017. godinu pokazuju da je prevalencija autizma najviša u Japanu i iznosi 161 na 10.000 dece. Na drugom mestu je Velika Britanija u kojoj je prevalencija autizma 94 na 10.000 dece, dok u Švedskoj iznosi 72 na 10.000 dece. Sa druge strane, Brazil, Hong Kong i Portugalija prijavljuju najniže vrednosti prevalencije, koje iznose 27, 17 i 9,2 na 10.000 dece (29).

Postavlja se pitanje koji su razlozi za porast prevalencije autizma. Dijagnoza autizma se sve češće postavlja počev od 1979. godine, a istraživanja koja su sprovedena objašnjavaju oko $50 \%$ porasta prevalencije autizma. Jedan od mogućih razloga za porast prevalencije autizma je promena dijagnostičkih kriterijuma tokom vremena. Godine 1952. autizam je definisan kao „šizofrenija sa ranim početkom". Tokom 1980. godine dobija novi naziv - „infantilni autizam”, a 1987. godine ponovo menja naziv u „autistični poremećaj”. Tokom prethodne decenije, uobičajeni naziv autizam pokriva čitav spektar bihejvioralnih, komunikacijskih i socijalnih poremećaja koji se jednim imenom nazivaju SAP, a koji uključuje autistični poremećaj, Aspergerov sindrom i ostale srodne poremećaje. Dijagnoza autizma je prilično subjektivna. Socijalne veštine osoba sa autizmom se razlikuju u mnogome u odnosu na opštu populaciju, kao i ostali oblici ponašanja koji su u sprezi sa autizmom. Postavlja se pitanje u kom trenutku odsustvo spontanosti i nemogućnost uspostavljanja kontakta očima predstavljaju medicinski problem. Drugim rečima, učestalost dijagnoze predstavlja odraz mogućnosti roditelja da prihvate dijagnozu. Na ovaj način može da se objasni jedan deo porasta prevalencije autizma (29). Prema Grinker-u dijagnoza je promenljiva i predstavlja okvir koji funkcioniše u određenom zdravstvenom i socijalnom sistemu, a menja se zajedno sa promenama u društvu. Ovakve tvrdnje su pomogle da se objasni porast prevalencije autizma, što je Grinker pokazao u studiji sprovednoj u Južnoj Koreji (30).

Peter Bearman, sociolog sa Univerziteta Kolumbija, pokušao je da poveže detaljne dijagnostičke podatke kako bi sagledao širu sliku demografskih karakteristika i lične istorije osoba sa autizmom, što je dalje dovelo do sagledavanja socijalnih faktora koji utiču na dijagnozu. Takođe, prema Bearman-u, oko 50\% zapaženog porasta prevalencije autizma može biti objašnjeno. Oko $25 \%$ porasta prevalencije autizma tokom prethodne dve decenije Bearman je pripisao tzv. „dijagnostičkom nagomilavanju“, tj. promeni dijagnostičkih kriterijuma koji idu u korist SAP. Analizom zdravstvenih kartona dece sa autizmom, zaključio je da ono što je u jednom trenutku dijagnostikovano kao mentalna retardacija, zapravo predstavlja autizam (31). Oko 15\% porasta prevalencije autizma može da se objasni povećanjem svesti o autizmu - sve više roditelja i pedijatara je upoznato sa ovim poremećajem (32). Prema Bearman-u, geografsko grupisanje objašnjava negde oko $4 \%$ povećanja prevalencije autizma. Najznačajniji klaster nalazi se u okolini Holivuda. Deca koja žive na teritoriji od $900 \mathrm{~km}^{2} \mathrm{u}$ okolini zapadnog Holivuda imaju 4 puta veći rizik za autizam 
ili poremećaj iz ovog spektra u odnosu na decu koja žive u nekom drugom delu Kalifornije (32). Oko 10\% povećanja prevalencije autizma može biti objašnjeno socijalnim promenama koje su, sa druge strane, uslovljene biološkim promenama: roditelji dobijaju decu u starijem uzrastu. Neka istraživanja su pokazala da deca čiji roditelji imaju više od 35 godina imaju veći rizik za razvoj autizma. Studije se dele na one koje su pokazale da godište majke ima značajan uticaj, kao i one koje su pokazale da je značajno godište oca, ali Bearman-ove studije koje su uključile roditelje starije od 40 godina pokazale su da je godište majke značajnije (33). Međutim, činjenica da $46 \%$ povećanja prevalencije ne može da se objasni ne znači da ovo povećanje predstavlja posledicu nekih novih zagađivača spoljašnje sredine (29).

\section{Autizam I MMR VAKCINA}

Veza između autizma i MMR vakcine učinila se prihvatljivom zato što se vakcinacija protiv malih boginja obavlja u drugoj godini života, a u to vreme, obično do uzrasta od 24 meseca, mogu da se zapaze prvi znaci autizma, bilo kao zastoj u razvoju ili kao gubitak već stečenih sposobnosti (regresija). Međutim, vremenska podudarnost ne znači da postoji uzročno-posledični odnos. Protiv uloge vakcinacije u nastanku autizma govori podatak da je učestalost ovog poremećaja nastavila da raste i u vreme kada je obuhvat vakcinacijom znatno opao širom sveta.

Godine 1998. dr Andrew Wakefield, britanski gastroenterolog, je u časopisu Lancet prikazao seriju slučajeva od 12 dece koja su se javila na odeljenje pedijatrijske gastroenterologije. U ličnoj anamnezi navedeno je da su deca imala normalan psihomotorni razvoj, ali su u jednom trenutku počela da gube prethodno stečene veštine (govor), uz dijareju i abdominalne bolove, a kod 9 njih postavljena je dijagnoza autizma. Deci su urađene sve gastroenterološke, neurološke i razvojne procene, kao i provera zdravstvenog kartona. Prema podacima koje su dali roditelji, simptomi kod dece poklapali su se sa vakcinacijom MMR vakcinom kod 8 od 12 dece, sa infekcijom virusom morbila kod jednog deteta, i zapaljenjem srednjeg uha kod ostalih. Dr Wakefield je u zaključku izneo moguću povezanost sa vakcinacijom MMR vakcinom, navodeći da je u seriji slučajeva koju je istraživao većina dece pokazala prve simptome autizma nakon vakcinacije (34). Uprkos maloj veličini uzorka, nedovoljno kontrolisanom dizajnu studije, kao i spekulišućoj prirodi zaključaka, rad je privukao veliku pažnju, a obuhvat MMR vakcinacijom je značajno opao, jer su roditelji bili zabrinuti rizikom za nastanak autizma nakon vakcinacije, pa je u nizu zemalja u kojima su male boginje bile već eliminisane došlo do njihove masovne pojave. (35).

Ubrzo počinju da se sprovode epidemiološke studije koje negiraju hipotezu o povezanosti između MMR vakcine i rizika za nastanak autizma $(36,37)$. Veza između MMR vakcine i rizika od nastanka autizma je sporna i zbog činjenice da je temporalna povezanost gotovo predodređena: oba događaja (MMR vakcinacija i autizam) dešavaju se u ranom detinjstvu (38). Prema navodima, „kauzalna povezanost između MMR vakcine i autizma nije pokazana jer su podaci nedovoljni“ (39). Takođe, Lancet se nakon toga izjasnio da je tokom istraživanja bilo sukoba interesa. Međutim, Wakefield i kolege su oslobođeni optužbe za kršenje etičkog kodeksa i naučno nepoštenje (40). Lancet je potpuno povukao rad u februaru 2010. godine, priznajući da nekoliko elemenata u radu nije bilo zadovoljavajuće, kao i da su oni u suprotnosti sa nalazima prethodnih istraživanja (41).

Od studije dr Wakefield-a do danas, preko 40 epidemioloških studija različitog dizajna prikazalo je da ne postoji povezanost između MMR vakcine i rizika za nastanak autizma.

Već 1999. godine Taylor i saradnici sprovode retrospektivnu analizu podataka o deci sa autizmom, koristeći kohortne dobne krive, kako bi pokazali da li vakcinacija MMR vakcinom zaista nosi rizik od nastanka autizma, kao i da li vreme vakcinacije utiče na pojavu simptoma. Pokazano je da uzrast u vreme dijagnoze ne zavisi od uzrasta u kome je data MMR vakcina, tj. da li je vakcina aplikovana pre ili posle usrasta od 18 meseci, a ni jedna od analiza nije ukazala na povezanost između MMR vakcine i autizma. Analiza serije slučajeva pokazala je da nema vremenskog grupisanja između MMR vakcine i dijagnoze autizma (36).

Do sličnih rezultata došla je i studija koja je ispitivala vremenske trendove autizma i vakcinacije MMR vakcinom u Kaliforniji. Dales i saradnici su zaključili da odsustvo povezanosti između temporalnih trendova MMR vakcinacije i broja SAP zapravo ne podržava hipotezu da je povećan obuhvat imunizacijom kod male dece povezan sa upadljivim rastućim sekularnim trendom SAP u Kaliforniji. Autori su istakli činjenicu da je obuhvat imunizacijom MMR vakcinom porastao u periodu od 1980. do 1994. godine, ali navedeni porast nije bio praćen porastom autizma, što je pokazala analiza kohortnih dobnih kriva (37).

Analiza vremenskih trendova u Velikoj Britaniji, koja je obuhvatila podatke iz medicinske dokumentacije lekara opšte prakse, kao i decu uzrasta do 12 godina koja su u periodu od 1988. do 1993. godine ispoljila simptome poremećaja iz autističnog spektra, pokazala je da je incidencija autizma kod dece uzrasta 2 do 5 godina značajno porasla u navedenom periodu, ali samo u datoj kohorti, dok je obuhvat imunizacijom bio viši od $95 \%$ za sve kohortne dobne grupe, tako da rezultati date studije nisu išli u prilog povezanosti između MMR vakcine i rizika za nastanak autizma. Dakle, ne postoji vremenska korelacija između obuhvata imunizacijom i incidencije 
autizma u svakoj analiziranoj kohortnoj dobnoj grupi u navedenom periodu. Autori su porast incidencije autizma koji je pokazan analizom zdravstvene dokumentacije dece objasnili delimičnimm porastom svesti o ovom poremećaju koji je zapažen ne samo kod zdravstvenih radnika, već i kod roditelja, ali i promenama dijagnostičkih kriterijuma, pa čak i mogućim sredinskim faktorima koji još uvek nisu identifikovani. Svakako, studija je obezbedila dokaze koji ne podržavaju hipotezu postavljenu 1998. godine (42).

Retrospektivna kohortna studija iz 2002. godine, koju su sproveli Madsen i saradnici u Danskoj, obuhvatila je reprezentativni uzorak od preko 500.000 dece rođene između 1991. i 1998. godine. Istraživanje je pokazalo da je u uzorku bilo vakcinisano više od $80 \%$ dece. Relativni rizik za nastanak autizma u grupi vakcinisane dece iznosio je 0,92, dok je kod nevakcinisanih iznosio 0,83. Takođe, povezanost između uzrasta u vreme dobijanja vakcine i autizma nije pronađena ni u ovoj studiji. Data studija je zapravo obezbedila tri snažna dokaza koja idu protiv hipoteze da je MMR vakcina povezana sa rizikom od nastanka autizma. Prvo, rizik od autizma je sličan i kod vakcinisane i kod nevakcinisane dece, i kada se analiza radi u ukupnom uzorku, ali i kada se radi uzrasno-specifična analiza. Drugo, i ova studija je pokazala da nema vremenske povezanosti između MMR vakcine i autizma. Treće, ni autizam, ali ni bilo koji drugi poremećaj iz SAP nije povezan sa vakcinacijom (43).

Japanska populaciona studija iz 2005. godine imala je isti cilj - da utvrdi da li postoji povezanost između MMR vakcine i rizika za nastanak autizma. Ključni rezultat ove studije bio je porast kumulativne incidencije SAP sa 47,6 na 10.000 dece koja su rođena 1988 . godine, na 117,2 na 10.000 dece rođene 1996. godine. Ono što je najznačajniji i najupečatljiviji nalaz u studiji jeste činjenica da su stope autizma nastavile da rastu i nakon povlačenja MMR vakcine iz upotrebe, i nisu smanjene u petogodišnjem periodu (1988 - 1992) tokom koga je obuhvat imunizacijom opao na samo $69,8 \%$. Ukoliko bi vakcina bila odgovorna za nastanak autizma, pad incidencije bi morao da bude uočljiv nakon povlačenja vakcine. Međutim, kontinurani porast incidencije autizma u suprotnosti je sa navedenim hipotezama. Autori su zaključili da, shodno rezultatima studija iz SAD i Velike Britanije u kojima se MMR vakcina kontinuirano koristi, povlačenje MMR vakcine u Japanu nije dovoljno da zaustavi porast incidencije autizma (44).

Značajni su i rezultati studije slučajeva i kontrola koja je imala za cilj da pokaže da li su deca koja imaju neki od poremećaja iz autističnog spektra bila izložena većem broju antigena koji su sadržani u vakcinama, u poređenju sa zdravom decom. Studija je uključila više od 700 dece bez pervazivnog poremećaja i više od 300 dece sa poremećajem. Sva deca bila su uzrasta 6-13 godina, a rođena između 1994. i 1999. godine. Autori su analizira- li izloženost antigenima od rođenja do 3. meseca, od rođenja do 7. meseca i od rođenja do 2. godine života. Takođe, analizirana je i ukupna izloženost tokom čitavog perioda. Pokazano je da deca koja su bila izložena većoj koncentraciji antigena tokom jednog dana, ili čak tokom čitavog perioda nisu bila u većem riziku od nastanka autizma. Takođe, pokazano je da porast izloženosti antigenima i rizik za nastanak autizma u srazmernom odnosu. Izlaganje dece većem broju imunogena tokom prve godine života ne povećava rizik za nastanak autizma, niti bilo kog drugog pervazivnog poremćaja (45).

Najznačajniji dokaz da ne postoji povezanost između MMR vakcine i rizika za nastanak autizma dali su sistematski pregled literature iz 2012. godine (46), koji je uključio 57 epidemioloških studija, sa 14.700 .000 dece i meta-analiza iz 2013. godine, koja je uključila 5 kohortnih i 5 studija slučajeva i kontrola (47). Rezultati meta-analize su pokazali da ni komponente vakcine (timerosal ili živa), kao ni aplikovanje polivalentne vakcine (MMR) ne nose rizik od nastanka bilo kog poremećaja iz spektra autizma.

Retrospektivna kohortna studija, koja je sprovedena u SAD-u 2015. godine, obuhvatila je više od 95.000 dece koja su imala stariju braću i sestre sa ili bez pervazivnog poremećaja. Studija je imala je za cilj da proceni frekvenciju poremećaja iz autističnog spektra među decom koja su imala, tj. nisu imala brata ili sestru sa ovim poremećajem. Pokazano je da MMR vakcina nije povezana sa rizikom od nastanka autizma, nezavisno od toga da li je dete imalo brata ili sestru kod kojih je prethodno postavljena dijagnoza nekog od poremećaja iz ovog spektra (48).

\section{Etiologija autizma}

I ako etiologija autizma nije sasvim razjašnjena, postoje snažni dokazi o prisustvu neurobiološke osnove sa značajnom genetskom komponentom kod obolelih, kao i moguća interakcija između gena i prenatalne životne sredine. Utvrđeno je da kod obolelih od autizma postoje sheme dezorganizacije korteksa u većini uzoraka, a dezorganizacija je prisutna u onim delovima koji su zaduženi za socijalno i emocionalno funkcionisanje, komunikaciju i jezičke sposobnosti. Ovakve abnormalnosti mogu predstavljati set razvojnih neuropatoloških karakteristika koje su u osnovi autizma, a verovatno su rezultat disregulacije i diferencijacije neurona u prenatalnim stadijumima razvoja (49).

Prema najnovijim leteraturnim podacima, morfološke promene mozga u uzrastu 6-12 meseci, dakle, pre dobijanja MMR vakcine, prethode kliničkom ispoljavanju autizma. Studija je upoređivala decu koja imaju porodični rizik za nastanak pervazivnog poremećaja sa decom kod koje je taj rizik mali. Pokazano je da je volumen 
mozga, tj.njegov ekscesivni rast povezan sa pojavom i težinom simptoma koji se sreću u okviru pervazivnog poremećaja. Algoritam koji je uključio površinu mozga dobijenu sa magnetne rezonance dece uzrasta 6-12 meseci predviđao je dijagnozu autizma kod dece uzrasta 2 godine, sa pozitivnom prediktivnom vrednošću od $81 \%$ i senzitivnošću od $88 \%$. Ovi rezultati ukazuju na činjenicu da se promene mozga koje prethode ispoljavanju kliničkih simptoma pervazivnog poremećaja dešavaju još tokom ranog razvoja (50).

\section{EPIDEMIOLOŠKA SITUACIJA MORBILA}

Još od vremena kada je dr Wakefield objavio rezultate svoje studije i doveo u vezu MMR vakcinu i autizam, obuhvat MMR imunizacijom počeo je da opada, bez obzira na mnogobrojne studije koje su iznele obilje dokaza da MMR vakcina ne povećava rizik od nastanka autizma. Ukoliko se analiziraju podaci SZO i obuhvat imunizacijom MMR vakcinom na globalnom nivou, zapaža se da je on u 2016. godini iznosio svega $85 \%$, što je nedovoljno da se održi dovoljno visok nivo kolektivnog imuniteta i spreče epidemije morbila. Imunizacija u ovom trenutku prevenira 2 do 3 miliona smrtnih ishoda svakoga dana. Sa druge strane, ukoliko bi se obuhvat imunizacijom povećao, to bi sprečilo dadatnih $1,5 \mathrm{mi}-$ liona smrtnih ishoda. Takođe, procenjeno je da u svetu 19,5 miliona dece nije dobilo obavezne vakcine (51).

U našoj zemlji, obuhvat imunizacijom je drastično opadao, počev od 2013. godine sa više od $92 \%$ na svega $81 \%$ koliko je iznosio tokom 2016. godine. U prvoj polovini 2017. godine obuhvat MMR vakcinacijom iznosio je samo $34,6 \%$, tj. za prethodnih 7 godina opao je za čak
$77,5 \%$. Naravno, to je dovelo do povećanja obolevanja od morbila, što je posebno izraženo 2014. i 2015. godine kada su stope incidencije iznosile 0,51 na 100.000 i 5,35 na 100.000 , u poređenju sa 2013. godinom kada je stopa incidencije iznosila samo 0,01 na 100.000 .

Od рос̌еtка окtobra 2017. godine, zaкljučno sa 14. 2. 2018. godine na teritoriji Republiкe Srbije, uкljučujući i teritoriju nadležnosti Zavoda za javno zdravlje Kosovsка Mitrovica, registrovana su uкupno 2222 slučaja malih boginja, od којih je 1138 laboratorijsкi potvrđeno u Institutu Torlaк. Pet osoba je umrlo zbog komplikacija ove bolesti (52).

\section{ZAKLJUČAK}

Prevalencija autizma je poslednjih decenija u porastu, ali ovaj porast može da se objasni bar jednim delom promenama u dijagnostičkim kriterijumima i porastom svesti o poremećaju, kako kod lekara, tako i kod roditelja i osoba koje su uključene u obrazovanje deteta. Rezultati brojnih epidemioloških studija, publikovani u eminentnim medicinskim časopisima, idu u prilog hipoteze da MMR vakcina ne povećava rizik za nastanak autizma. MMR vakcina je visoko efektivna u prevenciji morbila.

\section{Napomena}

Rad je izlagan na mini simpozijumu "Proslava 70 godina Instituta i Katedre za epidemiologiju Medicinskog fakulteta Univerziteta u Beogradu", na 46. simpozijumu Stremljenja i novine u medicini, Medicinski fakultet u Beogradu, 12.12.2017. godine.

\section{LITERATURA}

1. Matson JL, Boisjoli JA. Differential diagnosis of PDDNOS in children. RASD. 2007; 1:75-84.

2. Diagnostic and Statistical Manual of Mental Disorders (DSM IV). Fourth Edition. Am J Psychiatry. Washington DC. 2013.

3. Charman T, Baird G. Practitioner review: Diagnosis of autism spectrum disorder in 2- and 3-year-old children. J Child Psychol Psychiatry. 2002; 43(3):289-305.

4. Rondeau E, Klein LS, Masse A, Bodeau N, Cohen D, Guile' JM. Is pervasive developmental disorder not otherwise specified less stable than autistic disorder? A meta-analysis. J Autism Dev Disord. 2011; 41:1267-1276.

5. Lord C. Follow-up of two-year-olds referred for possible autism. J Child Psychol Psychiatry. 1995; 36(8):1365-1382.

6. Van Daalen E, Kemner C, Dietz C, Swinkels SHN, Buitelaar JK, Van Engeland H. Inter-rater reliability and stability of diagnoses of autism spectrum disorder in children identified through screening at a very young age. European child \& adolescent psychiatry. 2009; 18:663-674.

7. Olmsted D, Blaxill M. Leo Kanner's mention of 1938 in his report on autism refers to his first patient. J Autism Dev Disord. 2016; 46(1):340-341.

8. Lotter V. Epidemiology of autistic conditions in young children. Social Psychiatry. 1966; 1(3):124-135.

9. Rutter M. Aetiology of autism: findings and questions. J Intellect Disabil Res. 2005; 49(1):231-238.

10. Treffert DA. Epidemiology of infantile autism. Arch Gen Psychiatry. 1970; 22(5):431-438.
11. Fombonne E. Epidemiology of pervasive developmental disorders. Pediatr Res. 2009; 65(6):591-598.

12. Rice CE, Rosanoff M, Dawson G, Durkin MS, Croen LA, Singer A, et al. Evaluating changes in the prevalence of autism spectrum disorders. 2012; 34(2):1-22

13. Rutter M. Incidence of autism spectrum disorders: changes over time and their meaning. Acta Pediatric. 2005; 94(1):2-15

14. Baird G, Simonoff E, Pickles A, Chandler S, Loucas T, Meldrum D et al Prevalence of disorders of the autism spectrum in a population cohort of children in South Thames: the Special Needs and Autism Project (SNAP). Lancet. 2006; 368:210-215.

15. Bertrand J, Mars A, Boyle C, Bove F, Yeargin-Allsopp M, Decoufle P. Prevalence of autism in a United States population: the Brick Township, New Jersey, investigation. Pediatrics. 2001; 108:1155-1161.

16. Baron-Cohen S, Scott FJ, Allison C, Williams J, Bolton P, Matthews FE, et al. Prevalence of autism-spectrum conditions: UK school-based population study. Br J Psychiatry. 2009; 194:500-509.

17. Centers for Disease Control and Prevention. Autism Spectrum Disorder (ASD). Autism and Developmental Disabilities Monitoring (ADDM) Network. 2016.

18. Baio J. Prevalence of Autism Spectrum Disorders - Autism and Developmental Disabilities Monitoring Network, 14 Sites, United States, 2008. Morbidity and Mortality Weekly Report (MMWR). Surveillance Summaries. 2012; 61(SS03):1-19. 
19. Rice C. Prevalence of autism spectrum disorders: Autism and Developmental Disabilities Monitoring Network, United States, 2006. Morbidity and Mortality Weekly Report. 2009; 58(SS10):1-20.

20. Rice C, Braun KVN. Autism and Developmental Disabilities Monitoring Network, and Centers for Disease Control and Prevention. Prevalence of autism spectrum disorders-Autism and developmental disabilities monitoring network, six sites, United States, 2000; Prevalence of autism spectrum disorders-Autism and developmental disabilities monitoring network, 14 sites, United States, 2002; and Evaluation of a methodology for a collaborative multiple source surveillance network for autism spectrum disorders-Autism and Developmental Disabilities Monitoring Network, 14 sites, United States, 2002. Washington, DC: U.S. Government Printing Office; 2007.

21. Maenner MJ, Rice CE, Arneson CL, Cunniff C, Schieve LA, Carpenter LA, et al. Potential impact of DSM- 5 criteria on autism spectrum disorder prevalence estimates. JAMA Psychiatry. 2014; 71(3):292-300.

22. Shattuck PT, Durkin M, Maenner M, Newschaffer C, Mandell DS, Wiggins L, Lee LC, Rice C, Giarelli E, Kirby R. Timing of identification among children with an autism spectrum disorder: Findings from a population-based surveillance study. J Am Acad Child Adolesc Psychiatry. 2009; 48(5):474-483.

23. Durkin MS, Bilder DA, Pettygrove S, Zahorodny W. The validity and usefulness of public health surveillance of autism spectrum disorder. Autism. 2014; 19(1):118-119.

24. Fombonne E. A wrinkle in time: From early signs to a diagnosis of autism. J Am Acad Child Adolesc Psychiatry. 2009; 48(5):463-464.

25. Elsabbagh M, Divan G, Koh YJ, Kim YS, Kauchali S, Marcı'n C, et al. Global prevalence of autism and other pervasive developmental disorders. Autism Research. 2012; 5(3):160-179.

26. Hill AP, Zuckerman K, Fombonne E. Epidemiology of autism spectrum disorders. In Volkmar VR, Rogers SJ, Paul R, Pelphrey KA (Eds.). Handbook of autism and pervasive developmental disorders. Diagnosis, development, and brain mechanisms, 4th ed, Wiley, New York, 2014.

27. Montiel-Nava C, Peñ JA. Epidemiological findings of pervasive developmental disorders in a Venezuelan study. Autism. 2008; 12(2):191-202.

28. Pantelis PC. Kennedy DP. Estimation of the prevalence of autism spectrum disorder in South Korea, revisited. Autism. 2015; 1-11.

29. Weintraub K. Autism counts. Nature. 2011; 479(7371):22-24.

30. Kim YS, Lenethal BL, Koh YL, Fombonne E, Laska E, Lim EC, et al Prevalence of autism spectrum disorders in a total population sample. Am J Psychiatry. 2011; 168(9):904-912.

31. King M, Bearman, P. Diagnostic change and the increased prevalence of autism. Int J Epidemiol. 2009; 38(5):1224-1234.

32. King MD, Bearman PS. Socioeconomic status and the increased prevalence of autism in California. Am Sociol Rev. 2011; 76(2):320-346.

33. King MD, Fountain C, Dakhlallah D, Bearman PS. Estimated autism risk and older reproductive age. Am J Public Health. 2009; 99(9):1673-1679.

34. Wakefield AJ, Murch SH, Anthony A, Linell J, Casson DM, Malik M, et al. Ileal-lymphoid-nodular hyperplasia, non-specific colitis, and pervasive developmental disorder in children. Lancet. 1998; 351:637-641.
35. DeStefano F, Chen RT. Negative association between MMR and autism. Lancet. 1999; 353(9169):1987-1978.

36. Taylor B, Miller E, Farrington CP, Petropoulos MC, Favot-Mayaud I, Li J, et al. Autism and measles, mumps, and rubella vaccine: no epidemiological evidence for a causal association. Lancet. 1999; 353(9169):20262029.

37. Dales L, Hammer SJ, Smith NJ. Time trends in autism and in MMR immunization coverage in California. JAMA. 2001; 285(9):1183-1185.

38. Sathyanarayana Rao TS, Andrade C. The MMR vaccine and autism: Sensation, refutation, retraction, and fraud. Indian J Psychiatry. 2011; 53(2):95-96.

39. Murch SH, Anthony A, Casson DH, Malik M, Berelowitz M, Dhillon AP, et al. Retraction of an interpretation. Lancet. 2004; 363(9411):750.

40. Horton R. A statement by the editors of The Lancet. Lancet. 2004; 363(9411):820-821.

41. Eggertson L. Lancet retracts 12-year-old article linking autism to MMR vaccines. CMAJ. 2010; 182(4):E199-200.

42. Kaye JA, del Mar MeleroMontes M, Jick H. Mumps, measles, and rubella vaccine and the incidence of autism recorded by general practitioners: a time trend analysis. BMJ. 2001; 322:460-462.

43. Meldgaard Madsen M, Hviid A, Vestergaard M, Schendel D, Wohlfahrt J, Thorsen $\mathrm{P}$, et al. A population-based study of measles, mumps and rubella vaccination and autism. NEJM. 2002; 347(19):1477-1482.

44. Honda H, Shimizu Y, Rutter M. No effects of MMR withdrawal on the incidence of autism: a total population study. J Child Psychol Psychiatry. 2005; 46(6):572-579.

45. DeStefano F, Price CS, Weintraub ES. Increasing exposure to antibody-stimulating proteins and polysaccharides in vaccines is not associated with risk of autism. J Pediatr. 2013; 163(2):561-567.

46. Demicheli V, Rivetti A, Debalini MG, Di Pietrantonj C. Vaccines for measles, mumps and rubella in children. Cochrane Database Syst Rev. 2012; 15(2):CD004407.

47. Taylor LE, Swerdfeger AL, Eslick GD. Vaccines are not associated with autism: An evidence-based meta-analysis of case-control and cohort studies. Vaccine. 2014; 32:3623-3629.

48. Jain A, Marshall J, Buikema A, Bnacroft T, Kelly JP, Newschaffer CJ. Autism occurrence by MMR vaccine status among US children with older siblings with and without autism. JAMA. 2015; 313(15):15341540.

49. Stoner R, Chow ML, Boyle MP, Sunkin SM, Mouton PR, Roy S. Patches of disorganization in the neocortex of children with autism. NEJM. 2012; 370(13):1209-1219.

50. Hazlett HC, Gu H, Munsell BC, Kim SH, Styner M, Wolff JJ. Early brain development in infants at high risk for autism spectrum disorder. Nature. 2017; 542:348-351.

51. Immunization coverage. World Health Organization. Available from: http://www.who.int/mediacentre/factsheets/fs378/en/

52. Nepublikovani podaci Instituta za javno zdravlje Srbije „Dr Milan Jovanović Batut”. 